\title{
ANALISIS SIKAP SISWA TERHADAP MODEL PEMBELAJARAN DISCOVERY LEARNING PADA PEMBELAJARAN BIOLOGI SECARA DARING
}

\author{
Sri Sulastri 1), Taupik Sopyan 2), Yoyon Sutresna ${ }^{3)}$ \\ UUniversitas Galuh, Jl. R. E. Martadinata No.150, Ciamis, Indonesia \\ 2Universitas Galuh, Jl. R. E. Martadinata No.150, Ciamis, Indonesia \\ Email :sriaka35@gmail.com
}

\begin{abstract}
The purpose of this study was to determine students' attitudes towards the online Discovery Learning model. This research was conducted in a high school. The sample of this research is the students of class $\mathrm{XI}$, totaling 30 people. Sampling technique with saturated sampling technique. This research used an quantitative descriptive method. The instrument used is a questionnaire to measure students' attitudes towards the online Discovery Learning learning model which consists of 20 statements. The data obtained from the questionnaire is ordinal data. The data obtained were analyzed by ordinal regression analysis. The results showed that students' attitudes in responding to the online Discovery Learning learning model had good criteria. Based on the results of the study, it can be concluded that the online Discovery Learning learning model is good for use in biology learning.
\end{abstract}

Keywords: Discovery Learning, online learning, student attitudes

\section{ABSTRAK}

Tujuan penelitian ini adalah untuk mengetahui sikap siswa terhadap model pembelajaran Discovery Learning secara daring. Waktu Penelitian ini dilaksanakan di Sekolah Menengah Atas.. Sampel penelitian ini adalah siswa kelas XI yang berjumlah 30 orang. Teknik pengambilan sampel dengan teknik sampling jenuh. Penelitian ini menggunakan metode deskriptif kuantitatif. Instrumen yang digunakan adalah angket untuk mengukur sikap siswa terhadap model pembelajaran Discovery Learning secara daring yang terdiri dari 20 pernyataan .Data yang diperoleh dari angket adalah data ordinal. Data yang diperoleh dianalisis dengan analisis regresi ordinal. Hasil penelitian menunjukan bahwa sikap siswa dalam merespon model pembelajaran Discovery Learning secara daring memiliki kriteria baik. Berdasarkan hasil penelitian dapat disimpulkan model pembelajaran Discovery Learning secara daring , baik digunakan pada pembelajaran biologi.

Kata Kunci : Discovery Learning , pembelajaran daring, sikap siswa

Cara sitasi: Sulastri, S., Sopyan, T. \& Sutresna, Y. (2021). Analisis Sikap Siswa Terhadap Model Pembelajaran Discovery Learning Pada Pembelajaran Biologi Secara Daring. Bioed: Jurnal Pendidikan Biologi, 9 (2), 25-29. 


\section{PENDAHULUAN}

Belajar merupakan sebuah proses yang dilakukan seseorang untuk memperoleh suatu perubahan tingkah laku untuk mencapai sebuah tujuan yang diharapkan. Sesuai dengan pendapat Mulyono (2015:39) mengatakan bahwa belajar merupakan suatu proses atau usaha yang dilakukan individu untuk memperoleh perubahan tingkah laku yang dilakukan secara sengaja untuk mendapat perubahan yang lebih baik.

Pembelajaran daring merupakan bentuk pembelajaran/pelatihan jarak jauh yang memanfaatkan teknologi telekomunikasi dan informasi, misalnya internet, CD_ROOM (secara langsung dan tidak langsung). Pembelajaran daring menghubungkan pembelajar (siswa) dengan sumber belajarnya (database, pakar/instruktur, perpustakaan) yang secara fisik terpisah atau bahkan berjauhan namun dapat saling berkomunikasi, berinterasksi atau berkolaborasi (secara langsung/synchronous) dan (secara tidak langsung/asynchronous) Abidin et, al (dalam molinda 2020:65)

Menurut permendikbud No. 65 Tahun 2013 menyatakan bahwa kurikulum 2013 yaitu kurikulum yang menyempurnakan pola pembelajaran yang berpusat pada guru menjadi pola pembelajaran yang berpusat pada peserta didik, pola pembelajaran satu arah menjadi interaktif dan pola pembelajaran pasif menjadi pembelajaran aktif mencari. Pada konteks pembelajaran kurikulum 2013 sekarang menggunakan pendekatan saintifik yang didalamnya memiliki 3 model pembelajaran yaitu model pembelajaran Problem Based Learning (PBL), Project Based Learning (PJBL) dan Discovery Learning dan menuntut siswa agar lebih aktif, kreatif, berfikir kritis, terampil berkomunikasi, dan mampu mengembangkan kreativitasnya.

Pada penelitian ini, peneliti memperoleh informasi dari seorang guru Biologi di salah satu SMA tentang pembelajaran biologi, khususnya pada materi Sistem Pernapasan. Penerapan model pembelajaran di sekolah ini kurang bervariasi, sehingga membuat siswa jenuh dalam belajar. Dengan adanya permasalahan ini membuat siswa tidak menonjolkan keaktifan dan partisipasi alam proses pembelajaran. Bahkan media yang digunakan sangat terbatas sehingga dengan keadaan seperti ini siswa kurang aktif dalam belajar dan tidak tertanamnya rasa ingin tahu sehingga kemampuan siswa untuk memecahkan masalah masih rendah. Akhirnya hasil belajar siswa tidak sesuai dengan yang diharapkan. Sebagai seorang guru tentunya memiliki sebuah harapan dan usaha agar siswa selalu mengikuti proses belajar dengan aktif, baik dan memiliki ketertarikan yang tinggi terhadap materi pembelajaran yang diajarkan sehingga kompetensi yang diharapkan dapat tercapai. Namun kenyataannya jika dilihat dari sikap siswa pada saat mengikuti pelajaran masih rendah. Hal ini dapat diamati pada saat Kegiatan Belajar Mengajar (KBM) berlangsung, kebanyakan siswa kurang memberikan respon pada materi yang diajarkan, tidak adanya perhatian, tidak adanya rasa ingin tahu, dan tidak adanya timbul rasa senang dalam diri siswa pada saat mengikuti proses pembelajaran, oleh karena itu perlu adanya upaya dari guru untuk memperbaiki kondisi tersebut yaitu melalui pemilihan model pembelajaran yang tepat yang dapat direspon dengan baik pada saat pelaksanaan pembelajajaran. Pada pembelajaran yang dilaksanakan secara daring,pemilihan model pembelajaran perlu diperhatikan dengan baik.

Salah satu upaya untuk memperbaiki permasalahan pembelajaran diatas adalah dengan menggunakan model discovey learning. Sanjaya (2008) mengemukakan bahwa discovery learning merupakan suatu rangkaian kegiatan pembelajaran yang melibatkan secara maksimal seluruh kemampuan siswa untuk mencari dan menyelidiki secara sistematis, kritis, dan logis sehingga mereka dapat menemukan sendiri pengetahuan, sikap, dan keterampilan sebagai wujud adanya perubahan prilaku. Discovery learning merupakan suatu kegiatan pembelajaran yang menuntut siswa agar lebih aktif dan mencari penemuan pengetahuan dengan sendirinya sehingga menemukan hasil akhir. Beberpa hasil penelitian pada pembelajaran biologi, hasil penelitian Indriani (2020) menunjukkan bahwa penerapan model pembelajaran Discovery learning berpengaruh terhadap hasil belajar kognitif pada materi Virus. Hasil penelitian lain, Restanti R (2020) bahwa model Discovery learning dapat meningkatkan hasil belajar Biologi pada materi Keanekaragaman 
Hayati. Penerapan model Discovery learning secara daring masih jarang dilakukan , tetapi pada kondisi pandemic covid 19 ini, seorang guru harus mampu memilih model pembelajaran yang tepat dalam mengkaji materi-materi Biologi yang memiliki keragaman karakteristik. Berdasarkan hasil-hasil penelitian tersebut, tujuan penelitian ini yaitu untuk mengetahui sikap siswa SMA terhadap model Discovery Learning yang dilakukan secara daring pada materi Sistem Pernapasan

\section{METODE}

Penelitian ini menggunakan metode deskriptif kuantitatif, dengan disain survey untuk memperoleh informasi tentang sikap siswa terhadap pembelajaran dengan menggunakan discovery learning. Pembelajaran ini dilakukan secara daring pada materi Sistem Pernapasan. Sampel penelitian ini adalah siswa kelas XI yang berjumlah 30 orang. Instrumen yang digunakan dalam penelitian ini berupa angket. Angket untuk mengungkap sikap siswa terhadap penerapan model Discovery Learning terdiri dari 20 pernyataan dengan indikator terdiri dari menerima/tidak menerima stimulus, menunjukkan rasa senang/ tidak senang dalam pembelajaran, respon terhadap stimulus yang diberikan, kesungguhan, menghargai, tanggung jawab. Dilakukan uji validitas dan reliabilitas terlebih dahulu terhadap instrumen yang digunakan. Instrumen ini diberikan kepada siswa, sesudah pelaksanaan pembelajaran. Sintaks discovery learning direalisasikan dalam pembelajaran yang dilaksanakan menggunakan zoom meeting. Data yang diperoleh dianalisis dengan menggunakan analisis regresi ordinal untuk mengetahui kriteria sikap atau tanggapan siswa terhadap pembelajaran discovery learning secara online.

\section{HASIL DAN PEMBAHASAN}

Sikap siswa pada penerapan model discovery learning dalam kegiatan pembelajaran akan muncul ketika dihadapkan dengan sebuah permasalahan yang harus mereka rumuskan dan mencari jawaban dari setiap permaalahan yang muncul dari berbagai sumber belajar. Siswa cenderung utuk bertindak secara suka, bersifat positif (favorable) atau tidak suka, bersikap negatif (unforable) terhadap proses kegiatan pembelajaran berlangsung.

Pada penelitian online ini, komponen siswa yang diteliti pada pada kelas yang menggunakan pembelajaran daring menggunakan model Discovery learning, mencakup Indikator menerima/tidak menerima stimulus yang diberikan, menunjukkan kesenangan/ketidak senangan dalam pembelajaran, merespon/tidak merespon stimulus yang diberikan, menunjukkan kesungguhan/ketidaksungguhan dalam belajar, menghargai/tidak menghargai stimulus yang diberikan, dan bertanggungjawab/tidak bertanggungjawab jawab terhadap apa yang dikerjakan. Deskripsi data hasil penelitian sikap siswa pada penerapan model Discovery Learning disajikan pada tabel 1

Tabel 1 : Distribusi skor sikap pada penerapan model pembelajaran Discovery Learning

\begin{tabular}{|c|c|c|c|c|c|}
\hline \multirow{2}{*}{ No } & \multirow{2}{*}{ Indikator } & \multicolumn{2}{|c|}{ Rentang Ideal } & \multirow{2}{*}{$\begin{array}{c}\text { Hasil } \\
\text { penelitian }\end{array}$} & \multirow{2}{*}{ Keterangan } \\
\hline & & Minimal & maximal & & \\
\hline 1 & $\begin{array}{l}\text { Menerima/tidak menerima } \\
\text { stimulus }\end{array}$ & 60 & 240 & 208 & $\begin{array}{l}\text { Sangat menerima } \\
\text { stimulus }\end{array}$ \\
\hline 2 & $\begin{array}{l}\text { Menunjukkan } \\
\text { Rasa senang/ tidak senang dalam } \\
\text { pembelajaran }\end{array}$ & 80 & 320 & 273 & Sangat senang \\
\hline 3 & $\begin{array}{l}\text { Merespon/tidak merespon } \\
\text { stimulus yang diberikan }\end{array}$ & 60 & 240 & 200 & $\begin{array}{l}\text { Sangat merespon } \\
\text { stimulus }\end{array}$ \\
\hline 4 & $\begin{array}{l}\text { Menunjukkan } \\
\text { kesungguhan/ketidaksungguhan dalam } \\
\text { belajar }\end{array}$ & 80 & 320 & 274 & Sangat sungguhsungguh \\
\hline
\end{tabular}


5 Menghargai/tidak menghargai stimulus yang diberikan

6

Bertanggungjawab/tidak bertanggungjawab terhadap apa yang dilakukan

Jumlah total
60

60

400
240

240

1.600
206

209

1370
Sangat menghargai

Sangat

bertanggungjawab

Sikap siswa sangat baik

Berdasarkan hasil penelitian pada tahap ke-1 dengan indikator menerima stimulus hasil penelitiannya bahwa sikap siswa terhadap model discovery ini menunjukkan bahwa siswa sangat menerima stimulus. Pada tahap ke-2 dengan indikator kesenangan hasil penelitiannya menunjukkan bahwa siswa sangat senang dalam kegiatan pembelajaran. Pada tahap ke-3 dengan indikator merespon hasil penelitiannya menunjukan bahwa siswa sangat merespon stimulus yang diberikan. Pada tahap ke-4 dengan indikator kesungguhan, hasil penelitian menunjukkan bahwa siswa sangat sungguh-sungguh dalam kegiatan pembelajaran. Pada tahap ke-5 dengan indikator menghargai hasil penelitiannya bahwa sikap siswa terhadap model discovery learning menunjukkan bahwa siswa sangat menghargai stimulus yang diberikan. Pada tahap ke-6 dengan indikator bertanggungjawab hasil penelitiannya menunjukan bahwa siswa sangat bertanggungjawab terhadap apa yang dilakukannya. Secara keseluruhan berdasarkan data hasil penelitian menunjukkan bahwa sikap siawa terhadap model discovery learning yang dilaksanakan secara daring pada materi sistem pernapasan memiliki kriteria sikap sangat baik. Ini berarti siswa -siswa tersebut memberikan tanggapan positif terhadap pelaksanaan pembelajaran yang diikutinya.

Respon positif siswa pada penelitian ini, dipandang relevan dengan teori-teori atau hasilhasil penelitian pendukungnya. Discovery learning merupakan suatu kegiatan pembelajaran yang menuntut siswa agar lebih aktif dan mencari penemuan pengetahuan dengan sendirinya sehingga menemukan hasil akhir. Menurut Priansa (2017) bahwa Penerapan model pembelajaran discovery learning ini memiliki beberapa kelebihan yaitu: 1). Meningkatkan kemampuan siswa dalam memecahkan masalah, 2). Meningkatkan motivasi siswa, 3). Mendorong keterlibatan keaktifan siswa, 4). Siswa aktif dalam kegiatan belajar dan menggunkan kemampuannya untuk menemukan hasil akhir, 5). Timbul rasa puas bagi siswa sehingga mendorong siswa untuk melakukan penemuan lagi, 6). Siswa akan mentransfer pengetahuannya ke berbagai konteks, 7). Melatih siswa belajar mandiri.

Bagi beberapa siswa memang sulit untuk menemukan suatu konsep. Oleh karena itu siswa perlu adanya dorongan supaya mau belajar dengan senang, tidak jenuh, aktif dalam mencari sendiri pengetahuan secara mandiri. Oleh karena itu, Model pembelajaran discovery learning merupakan model yang tepat karena memiliki peran penting dalam proses pembelajaran sehingga siswa dapat menggali dan mencari sendiri pengetahuan, bahkan menemukan sendiri konsep-konsep melalui pemikiran sendiri. Maka penggunaan model discovery learning ditentukan oleh partisipasi siswa dalam melakukan pembelajaran, semakin aktif siswa mengambil kegiatan dalam pembelajaran semakin berhasil penggunaan model discovery learning tersebut.

Penerapan model discovery learning yang dilakukan secara daring, dilaksanakan tidak seideal pembelajaran secara luring, dan ini merupakan kelemahan yang harus dicari antisipasinya. Namun demikian, menjadi kebanggaan peneliti karena dalam kondisi pandemi yang pembelajarannya dilaksanakan secara daring, tetapi masih bisa menerapkan model pembelajaran yang berpusat pada siswa yang sesuai dengn tuntutan kurikulum 2013. Berdasarkan surat edaran dari Menteri Pendidikan dan Kebudayaan bahwa seluruh kegiatan pembelajaran dilakukan dengan sistem pembelajaran daring. Pembelajaran daring merupakan bentuk pembelajaran/pelatihan jarak jauh yang memanfaatkan teknologi telekomunikasi dan informasi, misalnya internet, CD_ROOM (secara langsung dan tidak langsung). 


\section{KESIMPULAN}

Proses pembelajaran Biologi secara daring dengan menggunakan model pembelajaran discovery learning dapat berlangsung dengan baik. Siswa memberikan respon positif dalam menerima stimulus yang diberikan, menunjukkan rasa senang dalam pembelajaran, menunjukkan kesungguhan dalam belajar menghargai stimulus yang diberikan, dan bertanggungjawab terhadap apa yang dikerjakan. Dengan demikian siswa bersikap baik terhadap model discovery learning yang dilaksanakan secara daring.

\section{DAFTAR PUSTAKA}

Abidin Zainal, et al. (2020). Pembelajaran Online Berbasis Proyek Salah Satu Solusi Kegiatan Belajar Mengajar Di Tengah Pandemi Covid-19. 5(1), 64-70. Jurnal ilmiah profesi pendidikan.

Indriani.(2020).Pengaruh Model Pembelajaran Discovery Leaning terhadap Hasil Belajar Kognitif Materi Virus pada Siswa Kelas X, Skripsi, Prodi Pendidikan Biologi, FKIP. Universitas Muhammadiyah Makasar.

Lestari, K. E. Dan Yudhanegara, M.R. (2017) Penelitian Pendidikan Matematika. Bandung Refika Aditama

Martisari, I. (2014). Perbedaan Hasil Belajar Menggunakan Strategi Pembelajaran Inquiri Dan Discovery Learning Dalam Mata Pembelajaran Biologi Siswa Kelas VIII Di SMP Penda Tawangmangu Tahun Ajaran 2013/2014. Skripsi Biologi. Fakultas Keguruan Dan IImu Pendidikan Universitas Muhammadiyah Surakata

Peraturan Menteri Pendidikan dan Kebudayaan Republik Indonesia Nomor 65 Tahun 2013 Tentang Standar Proses Pendidikan Dasar dan Menengah. 2013. Jakarta: Kementerian Pendidikan dan Kebudayaan Republik Indonesia.

Priansa, donni, J. (2017). Pengembangan Strategi \& Model Pembelajaran: Bandung. Pustaka Setia

Restanti,R .(2020).Meningkatkan Hasil Belajar Biologi Tentang Keanekaragaman Hayati Melalui Model Discovery Learning Siswa Kelas X IPA SMA Negeri 3 Madiun, Jurnal Revolusi Pendidikan, vol 3 (3), tahun 2020.

Sanjaya, W . (2008). Perencanaan Dan Desain Sistem Belajar. Jakarta. PT Fajar Interpratama Mandiri

Simbolon, E.R., Tampilow, F.S. (2015) Pengaruh Pembelajaran Berbasis Masalah dan Pembelajaran Kontekstual Terhadap Berfikir Kritis Siswa SMP. 7(1):99-104

Sipa. A. et al (2017). Pengaruh Model Pembelajaran Discovery Learning \Berbasis Pendekatan Saintifik Terhadap Hasil Belajar Afektif Siswa Pada Materi Virus Di Kelas X Sma Negeri 2 Kota Jambi.1-15

Widaningsih, Dedeh (2010). Perencanaan Pembelajaran Matematika. Paket Modul Pembelajaran. Bandung Rizqi Press 